\title{
Lengyel NórA*
}

\section{MEGKÜZDÉSI STRATÉGIÁK ÉS NARRATÍV IDENTITÁS FENYVESI JUDIT SZOCIÁLIS TESTVÉR ÖNÉLETÍRÁSÁBAN}

Kulcsszavak: nőtörténet, önéletírás, reziliencia, narrativ identitás

„Az önéletírások az egyének templomai."

Történészként és laikusként is hajlamosak vagyunk elfogadni, hogy a 20. század a nagy háborúk és a totalitárius rendszerek története. Ebben a történetben a női sorsokról szólva általában - legtöbb esetben forráshiányra hivatkozva - megelégszünk egy-egy rövid összefoglalóval. Témám akár le is zárhatnám a következő néhány mondattal: Fenyvesi Judit 1923. június 8-án született Nagyszalontán, Romániában. Zsidó családból származott, de a család keresztény hitre tért. Judit katolikus iskolába járt, majd apáca lett. A kommunizmus ideje alatt börtönbe zárták, majd tíz év múlva, kiszabadulása után előbb Bécsbe, végül az Egyesült Államokba, Buffalóba emigrált, ahol 2005-ben hunyt el. Élete végéig aktív tagja volt a Szociális Testvérek Társaságának. Egyre többen gondolják azonban, hogy a történelmet a test, a trauma, az identitás és az emlékezet oldaláról is meg lehet közelíteni, s hozzájuk csatlakozva, a fentieket - Fenyvesi Judit önéletírásának² elemzése során - közelebbről is megvizsgálom. ${ }^{3}$

Írásomban arra törekszem, hogy bemutassam, milyen megküzdési stratégiák jellemezték Fenyvesi Judit életét, s hogy identitásának narratív alakja hogyan alakult

* Lengyel Nóra (1992), doktorandusz, ELTE BTK Nőtörténeti Kutatóközpont.

1 Philippe Lejeune: Az önéletírás meghatározása. Helikon XLVIII(2002). 3. sz. 284. Úgy gondolom, hogy a Helikon folyóirat Autobiográfia-kutatásnak szentelt száma igen értékes összeállítás a témában, részben erre szeretném felhívni a figyelmet e tematikus számból választott mottóval.

2 Fenyvesi Judit: A Journey of Light in the Darkness. 2002.

3 Korábban már bemutattam ismeretterjesztő jellegű formában Fenyvesi Judit életútját. Lengyel Nóra: Rab és szabad, zsidó és keresztény, szolgáló és vezető - Fenyvesi Mária Judit hitvalló élete. Képmás Magazin. Megjelenés ideje: 2019. 02. 09. Elérhető: https://kepmas. hu/rab-es-szabad-zsido-es-kereszteny-szolgalo-es-vezeto-fenyvesi-maria-judit-hitvalloelete . 
önéletírásában, amely műfajhoz kapcsolódó elméleti megközelítéseket itt most nem fejtem ki. A dolgozat Philippe Lejeune definíciójára épít, miszerint az önéletrajz „prózában írt retrospektív elbeszélés, melyet valódi személy ad saját életéről, a hangsúlyt pedig magánéletére, különösképp személyiségének történetére helyezi”. ${ }^{4}$ A narrációk által létrehozott identitás vizsgálata során arról sem feledkezhetünk meg, hogy az identitás is befolyásolja a narrációt, főként igaz ez egy önéletírás esetében (visszatekintő jellegéből fakadóan).

Elemzésem során kiindulópontom Paul Ricoeur narratív önazonosságról szóló elmélete, ${ }^{5}$ amely szerint az azonosság az elbeszélő funkció nyomán jön létre. Ricoeur megjegyzi, hogy az azonosság kérdése kettős jelentése (idem - ugyanaz, ipse őmagaság) miatt igen nehézkes. Míg az idem az azonossághoz, az ipse az önmagasághoz kapcsolódik, s míg az azonosságból az állandóságra következtetünk, ez a fajta változásnélküliség az ipsében nem fejeződik ki. Tehát az állandóság és a változás közötti kapcsolatot kell górcső alá venni, amit az elbeszélés vizsgálata által tehetünk meg, mivel az elbeszélés azonossága mutatja majd meg a személy azonosságát. Ennek nyomán feltételezhetnénk, hogy az elbeszélt szöveg önmagában egységet formál, s így alapvetőnek tekinti az azonosságot. De vajon van-e ilyen egysége alapvetően minden élettörténetnek ${ }^{3}$ Fenyvesi Judit önéletírása szerkezetileg is két fő részre bomlik, mely 19 fejezetet ölel fel, és a második fô részben a fejezeteken belül alfejezetek strukturálják írását, amelyek olykor évszámmal, olykor alcímekkel vannak ellátva. Ezenfelül a bevezetőben a szerző kitér a szöveg keletkezésének körülményeire, ami szerint az első, a születéstôl az Egyesült Államokba történő emigrálásig tartó szakasz létrejötte részben Joan Albarella író buzdításának köszönhető, aki (mint barátja) sarkallta arra, hogy írja meg emlékeit (oralhistory módszerrel rögzítették, és

4 Az önéletrajzi paktumban található meghatározást Lejeune nem tartja kizárólagosan sajátjának, ennek ellenére is nevéhez kötjük e definíciót, mely megkerülhetetlen a témát illetően. Magyar fordításban Philippe Lejeune: Az önéletrajzi paktum. Ford. Varga Róbert. Fosszilia. I(2002). 4. 133. Az önéletírás irodalomelméleti és társadalmi nemi szempontú megközelítése sem egységes, ám a dolgozatnak nem célja áttekinteni pl. Paul de Man, Georges May, Barett J. Mandel, James Olney, Michael Beauyour, Elizabeth W. Bruss, Paul John Eakin, vagy Leigh Gilmore vonatkozó munkásságát. Meg kell azonban jegyeznem, hogy eltérő a vélekedés az önéletírás műfaji meghatározásával kapcsolatban Paul de Man és Philippe Lejeune között. Röviden és leegyszerűsítve: Lejeune szerint az önéletírás önálló múfaj, és az önéletírói paktum alapján adott a kerete, és az olvasó e szabályok alapján olvassa a szerzőt, míg Paul de Man szerint az önéletírás inkább olvasási mód, ami szerint minden szöveg lehet autobiografikus, ám a szerző e szövegekben megkettőződik. Paul DE MAN: Az önéletrajz mint arcrongálás. Ford. Fogarasi György. Pompeji VIII(1997). 97.

5 Paul Ricoeur: A narratív azonosság. Ford. Seregi Tamás. = Narratíuák 5. Narratív pszichológia. Szerk. László János-Tномка Beáta. Kijárat, Bp., 2001. 15.

6 Teszi fel a kérdést FeHÉr M. István: Sorsesemény és narratĩ identitás címú tanulmányában. Magyar Filozófiai Szemle LIX(2015). 4. sz. 18. 
ezután öntötték írásos formába). Később más barátai, többek között Evelyn Brady és Lisa Monagle, valamint Szabó Angéla szociális testvér is arra bátorították, hogy kiegészítve, publikálja a teljes önéletírását, amely így tehát több év alatt (1990-2002) jött létre. Az emigráció előtti és utáni részek közti különbség nyelvileg is testet ölt: az első rész egyszerübb, rövidebb mondatokból építkezik, míg a második részben hoszszabb, többszörösen összetett mondatokban fogalmaz az önéletíró.

Fenyvesi Judit életútját több trauma is terhelte, amelyek egyrészt identitásépíto, másrészt identitásromboló funkcióval is bírnak. ${ }^{7}$ Vizsgálom, hogyan építette be ezeket a traumákat a narratív én az identitásba.

Az azonosság Fenyvesi önéletírásán keresztül folytonosan építkezik és az azonosságból való kilépés helyett az azonosságba való belépés folyamatáról tanúskodik. Az önelsajátításon van a hangsúly, nem pedig az önmagából való kilépésen. Figyelembe kell vennünk önéletírásának elemzése során Heidegger Lét és idóben ${ }^{8}$ részletezett autenticitás-elméletének perspektíváját, s annak Kantra visszanyúló „amit meg kell tenni, azt meg is lehet tenni" gondolatát. ${ }^{9}$ Ez alapján, amit a morális tudat parancsol, azt meg lehet tenni, természetesen meg is lehet szegni, de nem mondható, hogy meg kell szegni. Amennyiben a narratív identitás elmélete nyomán elfogadnánk, hogy az azonosság adott, nem tudnánk rákérdezni, miben rejlik az. Ahogy Heideggernél, úgy a szerzőnél is elsődleges önmaga megtalálása, majd önazonosságának keresése. Talán leginkább azt mutathatjuk be az önéletírás elemzése során, hogy melyek azok a feltételek, amelyek között kialakul az autentikus-én fogalmi kerete. ${ }^{10}$

7 Az identifikációs hálózatról bővebben lásd Pintér Judit Nóra: A tudattalan identitás. Imágó Budapest II(2012). 2. sz. 67.

8 Martin Heidegger: Lét és idó. Ford. Vajda Mihály-Angyalosi Gergely-Bacsó BélaKardos András-Orosz István. 2. kiadás. Osiris, Budapest. 2001. 156.

9 Immanuel Kant: A tiszta ész kritikája. Ford. Kis János. Bp., Atlantisz. 2004. 629.

10 A dolgozatban nem érintem sem a kulturális emlékezet, sem az önéletrajzi emlékezet elméleti kérdéseit, így az emlékezés és a felejtés mozzanatai, sőt folyamata sem tárgya a vizsgálatnak. Igaz, hogy az önéletrajzi visszaemlékezésben az általam kiragadott emlékképek értelmezésem szerint olyan alapélményeknek tekinthetók, amelyek közelebb vihetnek a kollektív és kulturális emlékezet vizsgálatához, mivel generációs, egyéni és globális történetek kapcsolódnak össze a szövegben, de ez nem célja a dolgozatnak. Az összefüggésre rámutat Pataki Ferenc: Önéletrajzi emlékezet - Önismeret - Önéletirás. Pszichológia. XXVI(2006). 2. sz. 131. Emellett az önéletírás második részében annak vizsgálatára is lehetőség nyílik, hogy az önéletíró hogyan tudta meglévő kulturális emlékezetét az emigrációban lévő kulturális közegbe integrálni. Különösen érdekes lehet a transznacionális szempont rendi vonatkozása, amennyiben azt vizsgálnánk - nem kizárólagosan az önéletírás alapján -, hogy az önéletrajzíró a Szociális Testvérek Társasága romániai kerületében szerzett tapasztalatait, illetve kulturális örökségét hogyan ültette át az emigrációban és később a rend egyik elöljáró személyeként. 
Fenyvesi Judit Katalin zsidó családba született. Identitásának alapját családjában határozza meg. Apja Fenyvesi Ferenc, anyja Waldmann Erzsébet, mindketten zsidó felmenőkkel rendelkeztek, Nagyváradon éltek. „Minden, amit tudok az őseim történetérôl, az, hogy apai nagyapám rabbi volt. Nem vagyok biztos benne, hogy mikor jöttek Magyarországra, de az nagyon valószínú, hogy Németországból jöttek, ahogy azt a vezetéknevük mutatja. Az édesapám családja a nevüket Teitelbaum-ról Fenyvesire változtatta. Ez nagyon gyakori volt ezekben az időkben azoknál, akik asszimilálódni akartak egy új kultúrába. Az édesanyám oldalán, Géza bácsikám változtatta a nevét Waldmann-ról a magyar Szilágyira." ${ }^{11}$ Ahogy írja, életükben fontos szerepet töltött be a család, nagyszüleit, nagybátyjait és unokatestvéreit is név szerint ismerteti. Három nagybátyja közül kettő katolikus, egy protestáns hitre tért.

Édesapja gyógyszerészetet tanult Budapesten, és azért költözött Szalontára, mert mostohaapjától megörökölte a gyógyszertárat, amely központi eleme volt nemcsak Szalonta mindennapi, hanem Judit életének is. „Gyermekként besegítettem a gyógyszertárban, főként péntekenként, piacnapokon, amikor tele volt emberekkel. Megtanultam, hogyan kell eladni a dolgokat a vásárlóknak és nagyon büszke voltam, hogy képes voltam megcsinálni. Azt gondolom, hogy az édesapám boldog volt, hogy ott vagyok vele. Vasárnaponként a gyógyszertár zárva volt, de az emberek az ajtó előtt várakoztak. A gyógyszertár része volt a háznak, ahol laktunk. Én kérdeztem az ajtónál és az édesapám megmondta, hogy mi a szükséges áru, aztán én odaadtam a vásárlónak."12

Adott felekezeti identitását nem részletezi, mivel nem sok benyomás érte. A zsidóságot csak értelmiségi létében köti össze családjával.

Édesanyja szintén a nagyváradi katolikus gimnáziumban tanult, majd Budapesten, a Zeneakadémián végzett, franciául és németül is jól beszélt. Azt írja: „Korai emlékem anyámról, ahogy összehívott minket, három gyermekét a zongora köré és csodálatos dalokra tanított minket”. ${ }^{13}$ Édesanyja fontos eleme identitásának: „Nagyon csodáltam édesanyám szociális készségeit. [...] nagyszerủ háziasszony volt, aki tudja, hogy viszonyuljon mindenkihez. Csodálatos példakép volt: egyszerre volt példás anya, feleség és barát". ${ }^{14}$

Anyjuk naplót vezetett gyermekkorukról, amiből megtudjuk, hogy nőisége a narratív identitásán keresztül leginkább az anyaságban jelent meg. Judit önéletírásából kiderül, hogy anyja nehezen viselte, hogy szoptatós dajkát kellett hívnia, akihez egyébként Judit nagyon kötődött. Erről a jelenségről egy, a századfordulóból származó naplóból értesülhetünk, amelyet Gyáni Gábor elemzett, aki felhívta a figyelmet

11 Fenyvesi: A Journey of Light in the Darkness, 2002. 1.

12 Uo. 3.

13 Uo. 3.

14 Uo. 4. 
arra, hogy az anyai gyengédség és kötődés már a 19. század végétôl jellemezte az anyák egy rétegét biztosan. ${ }^{15} \mathrm{~A}$ napló alapján ismét érinti identitását: azt írja anyja, hogy Judit mint középső gyerek, megpróbálta megtalálni saját helyét és szerepét a családban. Erre Judit a következő megjegyzést teszi: „Úgy gondolom, nehéz időszak lehetett ez számomra”. ${ }^{16}$ A naplóból Judit kiemeli: „Nagyon boldog voltam, amikor olvastam a naplóban, hogy boldog gyerek voltam és az édesanyám és az édesapám minden reggel az én mosolyomra ébredt. A legnagyobb öröm, hogy megtudtam, hogy az édesapám kedvence voltam és a család kis Waldmann Erzsébetnek hívott engem, mert a megjelenésemben az édesanyám vonásait látták" ${ }^{17}$ Sokat jelentett neki, hogy hasonlít édesanyjára, akire minden szempontból példaképként tekintett.

Juditnak két testvére volt: a nővére, Mariann makacs és lázadó; a húga, Márta bájos, eredeti és nagyon népszerú társai között. Ahogy írja: „Mindketten nagyon tehetségesek és megnyerőek voltak. Én szerény voltam, csendes, introvertált típus”. ${ }^{18}$ Azt is megtudjuk, hogy nagyon magányos volt, mert sosem talált igaz barátokra.

Egyetlen ajándékot említ, amit szüleitől kapott: az édesanyjától kapott naplót, amit 12. születésnapjára azért ajándékozott neki, hogy ne érezze annyira egyedül magát. Judit azt írja, hogy egyetlen oldal maradt meg a naplóból, ahova édesanyja írta üzenetét, mert ezt az oldalt kitépte, magával vitte, a többit viszont elégette, amikor elhagyta Romániát.

Tanulmányai alatt nemcsak barátokat nem talált, hanem egyik tanárával is meggyúlt a baja. Az első esetet, amikor körmöst kapott az iskolában, így írja le: „Azt gondoltam ez a világ vége. Ez volt az első alkalom, amikor megütöttek. A szüleim sosem ütöttek meg. Fájdalmat és szégyent éreztem. Hazamentem és nem sírtam”. ${ }^{19}$ Végül szülei előtt kiderült, hogy mi történt az iskolában, és ezért magántanuló lett, amíg fel nem dolgozta a traumát. Több év után ment vissza az iskolába, ahol végül együtt tudott múködni az új tanárnőjével.

Gimnáziumi tanulmányait a Notre Dame de Sion nővérek bentlakásos nagyváradi leánylíceumában ${ }^{20}$ végezte, csakúgy, mint testvérei. „Ebben az idôben tettem meg a saját útkeresésem. Meg akartam találni a saját identitásom mint zsidó személy. Soha nem volt lehetőségem megtapasztalni mélyebb szinten.” ${ }^{21}$ Azt megtudjuk,

15 Gyáni Gábor: A nőiség mint narrativ identitás. = Szám-(és betü)vetés - Tanulmányok Faragó Tamás tiszteletére. Szerk. ŐRI Péter. KSH Népességtudományi Kutatóintézet, Bp., 2014. 11-22.

16 Fenyvesi i.m. 5.

17 Uo. 5.

18 Uo. 3.

19 Uo. 7.

20 A kongregációt 1843-ban alapították a Ratisbonne testvérek, akik megkeresztelkedett zsidók voltak, és elsődleges céljuk a zsidók keresztény hitre térítése volt.

21 Uo. 8. 
hogy a cionista mozgalomban ô maga is részt vett, zsidó dalokat és táncokat tanult meg, de lelkileg nem érintette meg egy rabbi beszéde sem. Ebben az iskolában találkozott először a katolikus hittel, szerette tanárait, de mégis honvágya volt és nehezen élte meg, hogy szüleitől elszakadva élt. Sokat volt szomorú ebben az időben is; fel kellett fedeznie, hogy tud önmaga lenni. ${ }^{22}$

Judit 1938. november 19-én keresztelkedett meg édesanyjával és testvéreivel együtt. A katolikus hittel való találkozása után kezd el szövegszerúen reflektálni igazán arra, hogy önmagát keresi. Identitásának megkonstruálása számtalan kérdés mentén halad az önéletírásban, amelyben nemcsak saját életének értelmét keresi, hanem az élet értelmét általában véve is.: „Folyton azon tűnődtem, mi értelme az életnek, de nem kaptam választ. Miért voltunk itt? Ez egy egzisztenciális válság volt az életemben”. ${ }^{23}$ György nevü szerzetes unokatestvérével tudta megbeszélni a hittel kapcsolatos kérdéseket. Lilla nevú unokatestvére, aki a keresztanyja lett, szintén szerzetesi életet élt, és ő tette fel a kérdést neki, hogy miért nem él vallásos életet. Innentől a szerzetesi lét iránt érzett elköteleződés erősen foglalkoztatta Juditot, visszaemlékezése alapján a Hear the Call címû́ mú nagy hatással volt rá, mert a Jeremiás próféta életérôl szóló könyvben azok a kérdések merültek fel, amik benne is: „Miért ő? Miért hívja [az Isten szolgálatra - L. N.]? Lehetséges ez?”. ${ }^{24}$

1940-ben történt, hogy úgy érezte, Isten valóban szolgálatra hívta őt, amit nagy csodának élt meg, azonban nem tudott beszélni szüleivel arról, hogy szerzetesnek áll a Sion-nővérek közé. Lelki vezetője (Suciu Ioan) azt tanácsolta neki, hogy várjon ezzel a bejelentéssel, az Isten megmutatja neki a megfelelő pillanatot.

1940 ezenkívül a második bécsi döntés (1940. augusztus 30.) éve is, amikor ÉszakErdélyt ismét Magyarországhoz csatolták. Ezt Judit nagy veszteségnek élte meg amiatt, hogy a Sion nővérek működését Nagyváradon megszüntették, mivel vezetői nem beszéltek magyarul (főként román és francia származású [nővérek] tanítottak az iskolában).

A líceum után orvosira jelentkezett, de a numerus clausus miatt nem fogadták el jelentkezését, pedig a szülei álma volt, hogy orvos legyen. Ez volt azonban az az év is, amikor értesült arról, hogy a Szociális Testvérek Társasága Szociális Szemináriumot indít Kolozsvár központtal (1939-ben indult). Bár nem adott diplomát az iskola, oklevelet kaptak. A szociális testvérek irányítása alatt, tanulmányai idején Fenyvesi Judit szociális munkát végzett, a szórványban élők vallásgyakorlását mozdította elő, lelki fejlődésüket segítette, mert a szórványvidékre akkoriban nem jutott pap.

1942 trauma volt életében, édesapja ekkor hunyt el. Judit szerint édesapjának megszakadt a szíve. Mivel az antiszemitizmus Nagyváradon és Nagyszalontán is

22 Uo. 9.

23 Uo. 10.

24 Uo. 14. 
olyan méreteket öltött, hogy Judit családja veszélybe került, édesapja másodjára is megpróbálta eladni gyógyszerészetét, mivel emigrálni akartak Ausztráliába, ahol már élt rokonuk. Az állam nem tette lehetôvé a terv megvalósítását, nem adhatta el boltját, és erősen felügyelték tevékenységét, mivel Szalonta értelmiségi köre hozzá járt kártyázni, továbbá annak köszönhetően, hogy hitelre is adtak gyógyszert, apjának széles vevő- (és adós)köre volt. Ezek után írt levelet édesanyjának, hogy beáll a Sionrendbe, de édesanyja megtiltotta neki. „Mindenemmel ellenzem. Ez nem neked való. Azt szeretném, hogy boldog légy, ahogy én voltam. Minden porcikámmal ellenállok ennek." 25

Ebben az időben ismét a nőiség jelenik meg az identitás narratív elemeként. Megtudjuk, hogy egy egyetemi hallgató iránt szerelembe esett Judit, és a férfi iránt érzett szerelme miatt elbizonytalanodott vallási életében, 1943-ban azonban anyja intése ellenére is eldöntötte, hogy fogadalmat tesz. ${ }^{26}$

A következő fejezetek az 1940 és 1944 közötti eseményeket dolgozzák fel, melynek során a zsidók deportálását, üldözését részletezi. Sokáig dolgozott azon, hogy családját megmentse az elhurcolástól, bízott benne, hogy mivel Szalontán igen kisszámú zsidó közösség élt és (eleinte) nem is állítottak fel emiatt gettót, meg fognak menekülni a deportálástól. Egyik testvére gyermeket várt, ez tovább erősítette hitét, hogy nem fogják őket bántani. Lelkiismereti kérdést csinált belőle, hogy hazaköltözzön-e családjához, hogy együtt éljék át a nehéz időszakot, vagy fogadja el a lehetőséget, hogy a Szociális Testvérek Társasága megóvja őt, anélkül, hogy valódi fogadalmat tenne rendjükben; ${ }^{27}$ magára ölthette a szürke testvérek ruháját. 1947-ben meggyőződésből kérte felvételét, és fogadalommal kötelezte el magát a Szociális Testvérek Társaságában.

1944-ben még találkozott Nagyváradon édesanyjával, de június 27-én elkezdődött a deportálás: nagymamáját, édesanyját és két testvérét is elhurcolták; a koncentrációs táborból többé nem tértek haza. A lelki traumák miatt a Társaság marosfői üdülőhelyére küldték, ahol néhány hetet töltött, majd Nagyváradra visszatérte után csatlakoztak a magyar kerületi noviciátushoz.

1944. augusztus 24-e a következő, ahonnan folytatja az eseményeket, amikor az oroszok megszállták Romániát. Szegvár, ahol éppen tartózkodtak, nagyon veszélyessé vált, ahogy írja, nagyon rémisztő volt ez a tapasztalat számára, mert az oroszok megerőszakoltak minden nőt, akit csak találtak. ${ }^{28} \mathrm{Az}$ is kiderül, hogy testi védelmük miatt kezdtek el fátylat hordani ebben az idóben, ami egyébként a szociális testvérek egyenruhájának nem volt jellemző része. Egy nagyobb csoporttal vonatra szálltak, és

\begin{tabular}{ll}
\hline 25 & Uo. 17. \\
26 & Uo. $18-19$. \\
27 & Uo. 22. \\
28 & Uo. 26.
\end{tabular}


Győr, továbbá Szombathely érintésével a Balatonhoz utaztak Zamárdiba, ahol egy gyerektáborban húzták meg magukat két hétig. Innen egy faluba mentek Kis György atya közösségébe.

Ismét a nőiség, s még inkább a hozzá kapcsolódó áldozatiság jelenik meg identitást formáló erőként. Egy orosz katona megpróbálta megerőszakolni, de elmenekült: „Az egyik orosz katona egy üres szobába kényszerített, és megpróbált megerőszakolni. Nem emlékszem, hogy, de megláttam egy nyitott ablakot. Kiugrottam és futottam. A katona a fegyverével lőtt utánam. Csak futottam és futottam”. ${ }^{29}$ Végül egy faluba ért, ahol egy pincében bújt el, másokkal együtt. ${ }^{30}$

Az önéletírásnak egyelőre csak egy változatát ismerem, így nem érintem a dolgozatban például, hogy a család genealógiájának ismertetése hogyan alakult a különböző szövegváltozatokban, vagy azt, hogy egyes traumák fokozatosan váltak-e a személyiség részévé a szövegeken keresztül. Meg kell jegyeznünk, hogy Fenyvesi Judit felnőtt korában pszichológiát tanult az Egyesült Államokban, ezért speciális tudással rendelkezhetett akár az identitás, akár a traumák vagy az emlékezet kérdésében. Önéletírásához több forrást is felhasznált, néhányra hivatkozik is, köztük pl. Viktor Frankl munkájára, aki holokauszttúlélőként fogalmazta meg saját megküzdési stratégiáját. Ez a narratív azonosság kialakítása során mintaként is szolgálhatott Fenyvesi Judit számára. ${ }^{31}$

1948-tól elindult Kolozsváron a katolikus ellenállási mozgalom, amiben Judit is aktív szerepet vállalt, Bukarestben közremúködött a Szentszék és az egyházmegyék

29 Uo. 28. Bár a dolgozatnak nem célja más visszaemlékezésekkel összehasonlítani a vizsgált önéletírást, azonban érdekes lehet az olvasó számára, hogy Polcz Alaine háborús naplójában található egy hasonló rész, azzal a különbséggel, hogy Polcz megjegyzi, hogy ha meg akarták volna ölni, megtették volna: „Egyik éjszaka kiugrottam az ablakon. Nem tudom, akkor volt-e, hogy kigyulladt a ház, vagy máskor, és azt se, miért menekültem előlük, tény, hogy kiugrottam, mezítláb, egy szál ruhában. Ki a hóra, át a kerítésen, és szaladtam. Utánam Filike. Ők pedig lőttek rám. Szépen körbelőttek géppisztollyal”. Polcz Alaine: Aszszony a fronton. Egy fejezet életemból. Szépirodalmi, Bp., 1991. 46.

30 Alapvető szakirodalomként említenem kell a háborús nemi erőszakról: Pető Andrea: Elmondani az elmondhatatlant. Jaffa, Bp., 2018.; a nemi erőszak elbeszélési technikáiról: Kunt Gergely: Kipontozva... Nemi eröszak második világháborús naplókban. Osiris, Bp., 2019., az életírás és a traumák összefüggéséről társadalmi nemi (gender-) szempontú értelmezésben, mely nemzetközi szakirodalomban igen gazdag: Louise O. VAsvári: Életírás, társadalmi nemek és trauma. TNTeF = Társadalmi Nemek Tudománya: Interdiszciplináris eFolyóirat VI(2016). 2. sz. 150-197. Az én-azonosság kérdésének vizsgálatához számos szempontot ad Kövér György: Én-azonosság az ego-dokumentumokban. Napló, önéletírás, levelezés. Soproni Szemle. LXV(2011).3. sz. 219-242.

31 A kognitív narratológia területét a dolgozatban nem érintem, azonban feltételezem, hogy a vizsgált szöveg létrejöttekor az egyes szövegek, szövegrészek befogadása és feldolgozása az író szövegprodukciós tevékenységére is hatással lehetett. A tudástranszfer jelenlétére az önéletírásban többször reflektál a szerző. 
közötti kapcsolattartás megvalósításában, amit az állam tiltott. Ezért 1951. április 22-én éjjel letartóztatták két rendtársával együtt, és tíz év szabadságvesztésre ítélték. $A$ vád az volt, hogy titokban leveleket küldtek egyházi személyekhez.

Az önéletírásban három dolgozatot említ, melyet tanulmányai alatt írt saját sorsáról, amelyek közül egy szamizdatban is elterjedt. Az egyik ilyen, 1966-ban íródott dolgozat ${ }^{32}$ egy 18 oldalas változatát őrzik Kolozsváron a Szociális Testvérek, amelylyel röviden összevetem a kommunista időszak börtönlétét az önéletírásban szintén ez időszakra vonatkozó részekkel. A dolgozatban csoportosítja a kommunisták eljárási rendjét azok esetében, akik legalább tíz évre börtönbe kerültek. Az első szakasz a letartóztatás, a kihallgatás, és az ,igazság” kiderítése. Erre az igazságra többször utal önéletírásában is, hogy a legtöbb esetben az igazság az áldozatok szerint nem volt bűn, vagy csak a vallatások után vették észre, hogy elmondták az igazságot, amit a kommunisták a vádlott ellen fel tudtak használni. A második szakasz az elfogatás után a börtönhöz, kényszermunkához való szoktatás volt. A harmadik szakasz a szigorított börtönbüntetés ideje, a tétlenség. Mindkét írásban megjelenik a bekötött szem, az abból adódó félelem, majd a kihallgatás során az erősen remegő kéz, ugyanis arra kényszerítették, hogy írja le, amit tud: kinek írtak leveleket, és kik írtak leveleket. A kihallgatás néhány hónaptól néhány évig is tarthatott, ez mutatta, hogy menynyire tartották jelentősnek az adott személyt és munkáját a földalatti tevékenységben. A dolgozatban tipologizálja a kihallgatás módszereit is, erről ilyen összegző formában az önéletírásban nem olvashatunk. A módszerek között volt a járatás, amikor 48 órán keresztül jártak körbe a foglyok mezítláb a cement padlón, 3-4 óránkénti rövid megállással. A következő a skatulya, amikor a foglyot egy fémládába zárták, amelyben nem tudott sem ülni, sem lépni, csak állni, akár napokig. A kínzás és verés minden formáját felsorolja, fogak kiverésén keresztül, a halláskárosodás okozásáig, a talpak kínzó verésén át. A sötét cella módszerével, ami egy levegőtlen, piszkos verem volt, sokakban lelki összeomlást idéztek elő.

Az önéletírásból kiderül, hogy több börtönben is volt, a kihallgatások és a büntetések fázisai szerint. A dolgozatban az első börtönt, a jilavait ismerjük meg, amit a cellák és annak egyik, végig ablakkal ellátott fala jelez, mely a két szövegben megegyezik. Szintén közös elem, hogy padon aludtak, igaz, nem lett volna szabad lehunyni a szemüket. Az önéletírásból megtudjuk, hogy nem volt WC, nem volt mosakodási lehetőség, az egyik hordóba végezték dolguk, a másikból ittak (persze nem volt elegendő ivóvizük sem). Ebből a tranzitbörtönből egy másik hasonlóba szállították, Ghenceába, innen pedig munkatáborba, amelyet nem nevez meg. A téli hónapokban a szabad ég alatt dolgoztak, amit egy idő után nem bírt fizikálisan elvégezni, ezért ő hordta a vizet a többieknek, aminek apropóján megtalálta az utat, hogy néhány szót

32 FenYvesi Judit: Fénysugár a sötétségben. Nök a vasfüggöny mögötti börtönökben. Buffalo, 1966. Kézirat. 
váltson rabtársaival. A munkatáborból az Asszonyvásárán (Târgușor) lévő börtönbe szállították, ahol nem volt feladatuk; nem tudták, hogy meddig maradnak itt, vagy hogy miért kerültek ide, viszont itt megtalálták a módját, hogy hitrôl és Istenről kommunikáljanak egymással. Innen a misleai, politikai foglyoknak fenntartott női börtönbe vitték. Az önéletírásból kiderül, hogy itt dolgoztatták őket: egyrészt perzsaszőnyeget, mások férfiingeket készítettek. Ô mindkét folyamatban dolgozott, 12 órás munkaidejük volt. Mislea 1956-os bezárása után a csíkszeredai, szintén női politikai börtönbe szállították, az önéletírásból megtudjuk, hogy Krisztina testvérrel sok időt töltött itt együtt. Ezen a helyen, ahol Judit öt évet töltött, az udvarra naponta kimehettek 10-15 percig, azonban tilos volt egymással érintkezni. Ezt a kis szabadságot is azonnal megvonták, ha szabálytalanságon érték őket. Kommunikálni leginkább úgy tudtak, hogy szappanba véstek egy-két szót, de lebukás esetén minden szabályszegésért súlyos büntetés járt. Kb. 12 nővel volt egy cellába zárva. Ruhájukat egyenruhára kellett cserélni: csíkos szoknya, mellény, kabát, sapka, cipő; ez azonban a fútés nélküli helyiségekben igen szerény öltözéknek minősült. Itt titokban tanították egymást, angolul meséltek történeteket. Dolgozatában többször említi, hogy a csoporttagság segítette ôket a túlélésben és a csoportidentitás adta meg az ellenálláshoz az erőt. Ezt beszélgetések, imádkozások alkalmával erősítették meg, amik megvalósulására az önéletírásban csak ritkán tér ki, a rövid dolgozatban azonban többször említi. A gyerekes viselkedés megjelenésérôl is ír, ami veszekedésekben, majd azonnali kibékülésekben testesült meg, vagy a speciális, ételért vívott, hazugságon alapuló küzdelmekben. Pusztított a TBC és több más betegség, orvosi ellátás pedig alig akadt, ezért egyetlen megkülönböztetés a kosztban érte a betegeket, így érthető volt a foglyok ez irányú viselkedése. Akadtak, akik mások javára böjtöltek bizonyos napokon, hogy egymást segítsék, és így saját hitüket is erôsítették. A munkában is összefogtak, s néhányuk között valódi barátságok köttettek.

Miután tíz év börtönben töltött év után szabadult, előbb Bukarestben, majd Kolozsváron próbált letelepedni, de „büntetett elóélete miatt” ezek a városok nem fogadták be. Végül Szamosújváron kapott munkát és szállást. Két év elteltével, 1963 őszén felkerült egy kivándorló zsidó csoport listájára, akik Bécsen keresztül mehettek Izraelbe. Bécsben - bár helyzete eleinte kilátástalannak tűnt - Juditnak sikerült elérnie, hogy Izrael helyett az Egyesült Államokba emigrálhasson. Fenyvesi Judit egész életét a testvérközösségben való munka határozta meg, de 1970-től a Daemen College (akkor Rosary Hill College) falai között a tanári pályát is elvállalta; 17 évig tartó karrierjére úgy emlékezett vissza, mint aminek minden napja ajándék volt az Úrtól. 1985-ben általános elöljárónak választották meg a Szociális Testvérek Társaságában, így meg kellett fontolnia, hogy sokrétű hivatásából egészségileg mit vállalhat a gyakorlatban. Végül 1987-ben elköszönt a tanári pályától, így 1991-ig teljes figyelmével és energiájával végezhette elöljárói feladatait, melyekkel a testvérek kitüntették. 
Ezekre az évekre itt most részletesen nem térek ki, azonban még egy traumára kitekintek az önéletíró életének ebből a szakaszából, ami szintén a nőiséghez kötődik a narratív identitásban. Ilyen mértékű fizikális és lelki megpróbáltatás után talán nem meglepő, hogy több betegség is elérte Fenyvesi Juditot, ám mind közül a rák viselte meg leginkább. Emlődaganatáról és a szükséges mütétről így ír: „Miután annyi kihívással szembe kellett néznem életem során, néhányan furcsának találták, hogy ez a tény annyira megrázott, pedig ez történt. Annak a kérdése volt, hogy elveszítem fizikális önazonosságom; nem tudtam elképzelni magamat így egy egészként. Végtelenül fájdalmasnak találtam így magamra nézni. Bizonyos tekintetben, mellem elvesztése az egyetlen megtapasztalása volt nőiségemnek". ${ }^{33} \mathrm{~A}$ rákkal többször is megküzdött életében, amelynek során mindig talált társat, aki mellette állt a betegségben, a közösségből merített erőt.

Tanulmányom részben reflektált Rebecca Hogan azon - nem gendersemleges megközelítésére, miszerint az önéletírás férfi(as) műfaj; ${ }^{34}$ a fentebb elemzett önéletírás központi szereplője és szerzője nő. Ennek ellenére is egy gondosan szerkesztett, befejezett munkával van dolgunk, tehát a részben Rebecca Hogan által felvetett kritériumoknak megfelel az elemzett mú, így cáfolható, hogy ne lenne egyben női múfaj is az önéletírás. ${ }^{35}$ Ezenkívül a dolgozat cáfolja Radstone azon elméletét ${ }^{36}$ is, miszerint a női életírások nem kapcsolódnak a klasszikus történelmi korszakokhoz, hiszen a 20. század meghatározó politikatörténeti eseményeivel számos ponton találkoztunk az önéletírásban.

Az önéletírás lezárásaként szerzője a következőket szánja: „79 évesen úgy érzem, hogy körbe ért az életem, visszatérve a kezdetekhez; a családomhoz és az élethosszig tartó zsidó-keresztény küzdelemhez" ${ }^{37}$ Ezek alapján is elmondható, hogy egy célirá-

33 Uo. 81-82.

34 Rebecca Hogan: Engendered Autobiographies. The Diary as a Feminine Form. Prose Studies: History, Theory, Criticism, 14(2). 1991. 96.

35 A nők önéletírásáról, elvetve a maszkulinitást mint kizárólagos megközelítési módot lásd pl. Decolonizing the Subject. The Politics of Gender in Women's Autobiography. Szerk. Sidonie Smith-Julia Watson. University of Minnesota Press, Minneapolis, 1992.; Sidonie Smith, and Julia Watson szerk. Women, Autobiography, Theory: A Reader. University of Wisconsin Press, Madison. 1998. A múfaj és társadalmi nemek (genre és gender) kapcsolatának más szempontú megközelítését lásd Sidonie Smith and Julia Watson: „New Genres, New Subjects: Women, Gender and Autobiography after 2000.” Revista Canaria de Estudios Ingleses LVIII(2009). 13-40.

36 Susannah Radstone: „Autobiographical Times.” = Feminism and Autobiography: Texts, TheoriesEMethods. Szerk. Tess Cosslett-Celia Lury-Penny Summerfiel D. Routledge, London, 2000. 201-219.

37 Uo. 137. Ezen a ponton meg kell jegyeznem, hogy elfogadhatónak tủnik H. Porter Abott véleménye, miszerint az önéletírás vége az írás során végig jelen van. Porter $\mathrm{H}$. Аввотт: 
nyos szövegről van szó. Illeszkedik ehhez a könyv borítója ${ }^{38}$ is, melyen a cím alatt a háttérben, ám de középpontban egy közösséget látunk, amelyet különböző életkorú személyek adnak. A közösség egyrészt egy Dávid-csillag előtt áll, ám a mögötte lévő fénysugár egy keresztet ábrázol. Magam részéről befejezésül visszatérek a dolgozat elméleti hátteréhez, a Ricoeur-féle narratív azonosság kérdéséhez, ám összefoglalás helyett az önéletíró, Fenyvesi Judit börtönéveiről szóló dolgozatából idézek:

„Ha e beszámoló írója most megpróbálná felülvizsgálni saját tapasztalatait ráhatásokat, amelyeket az eröszakosan módositott szerepváltozás ${ }^{39}$ okozott, választ kellene adnia erre a kérdésre: mikor kiszabadult, olyannak találta-e magát, mint azelőtt? Erre a kérdésre kettős válasz adható. Azt nem állíthatja, hogy mindazon »tapasztalatok" után, melyeken keresztül ment, teljesen ugyanaz maradt. El kell ismernie, hogy »egy bizonyos szempontból a személyiség a személyiség története«. [...] Másrészről úgy érzi, hogy személyisége alapjában véve ép és változatlan ${ }^{40}$ maradt. Meg van győződve arról is, hogy helyzetének belső kiértékelése volt az igen fontos tényező alapvető magatartásának folytonos ${ }^{41}$ fenntartásában”. ${ }^{42}$

Írásomban részben azt vizsgáltam, hogy a személyes azonosság aspektusai között a narratívák (pl. napló, háború, menekülés, rabság, börtön, kivetettség, emigráció, újrakezdés, betegség stb.) hogyan közvetítenek. Arra is kitértem, hogy a narratív identitás elmélete az elbeszélt történeteket egységként és önazonosságként kezeli, amely egység azonban korántsem magától értetődő. Megmutattam, hogy az önazonosság megtalálása után az önmagunkból való kilépés igényére a szubjektum nincs kiszolgáltatva, hanem önmaga adhat választ önazonosságához mérten, így maradva autentikus önmaga.

Végezetül azt gondolom, hogy történészként és laikusként is meg kell ismernünk, hogy a családok és a nők sorsa hogyan kapcsolódik össze a nagy háborúk és a totalitárius rendszerek történetével. A dolgozatban kísérletet tettem arra, hogy bemutassam, hogy a mély vallásosság és a szerzetesi életmód milyen önállósulási lehetősége-

Önéletírás, autográfia, fikció: kisérlet a szövegtipusok osztályozására. Ford. PÉti Miklós. Helikon. XLVIII(2002). 3. sz. 286-304.

38 Ld. Melléklet. A borítót Jon Valerio tervezte.

39 Kiemelés tőlem - L. N.

40 Kiemelés tőlem - L. N.

41 Kiemelés tőlem - L. N.

42 Fenyvesi: Fénysugár a sötétségben. 18. Kéziratos formáját hivatkozom. Románia. Kolozsvár (Cluj-Napoca). Szentlélek Ház: a Szociális Testvérek Társaságának Romániai Kerületének központi irattára. 
ket és reziliens magatartást tett lehetővé az adott korszak(ok)ban és az adott ter(ek)ben a nők számára.

\section{MECHANISMS OF COPING AND NARRATIVE IDENTITY IN THE AUTOBIOGRAPHY OF JUDIT FENYVESI, A MEMBER OF THE SISTERS OF SOCIAL SERVICE}

\section{Keywords: women's history, autobiography, resilience, narrative identity}

In my paper I examine Sister Judith Fenyvesi's biography A Journey of Light in the Darkness, in line with a focus on narrative identities and resilience.

The biography is about a woman who is born in Jewish middle class family, but she had to become Catholic; because she was a persecuted person in Romania during the Nazism and the communism, and eventually emigrated to Buffalo (USA). Her life was characterized by the most determined events of the $20^{\text {th }}$ century and its aftermaths. The examined path of life was conditioned by the II. World War, the Holocaust, the Catholic Resistance movement, her imprisonment, the preparation for a new life and also her cancer. Although in this paper I focus on mechanisms of coping instead of victimhood narrative, as does the presented biography. While a variety of definitions of the term biography have been suggested, this paper is based on the definition of autobiography by Philippe Lejeune and on the theories of narrative identity of Paul Ricoeur.

\section{MECANISME DE REZILIENTĂ SI IDENTITATE NARATIVĂ ÎN AUTOBIOGRAFIA' LỦI JUDIT FENYVESI, MEMBRĂ A SERVICIULUI SOCIAL „SOCIETAS SORORUM SOCIALIUM”}

\section{Cuvinte-cheie: istoria feminității, memorialistică, identitate narativă}

În acest studiu abordez cartea autobiografică A Journey of Light in the Darkness de Judit Fenyvesi soră caritabilă și interpretez relația dintre identitățile sugerate de text și reziliența de caracter.

Este vorba de memoriile unei persoane care s-a născut într-o familie de evrei și care ulterior a optat pentru religia romano-catolică. In timpul dominațiilor naziste respectiv comuniste a fost persecutată și în final a emigrat în Buffalo. Întreaga viaţă i-a fost marcată de evenimentele definitorii ale secolului al XX-lea respectiv de urmările acestora. Acest parcurs a fost condiționat de cel de-al doilea Război Mondial, de Holocaust, de rezistența catolică, de viața din închisoare, de căutarea unui nou domiciliu, respectiv de povara mai multor boli severe. Studiul însă, în locul unei narațiuni de sacrificii, se concentrează asupra strategiilor de înfruntare imanente textului autobiografiei. Analizând memoriile redactate în limba engleză lucrarea se bazează înainte de toate pe definiția autobiografiei dată de Philippe Lejeune precum și pe abordarea teoretică a auto-identității elaborată de Paul Ricoeur. 


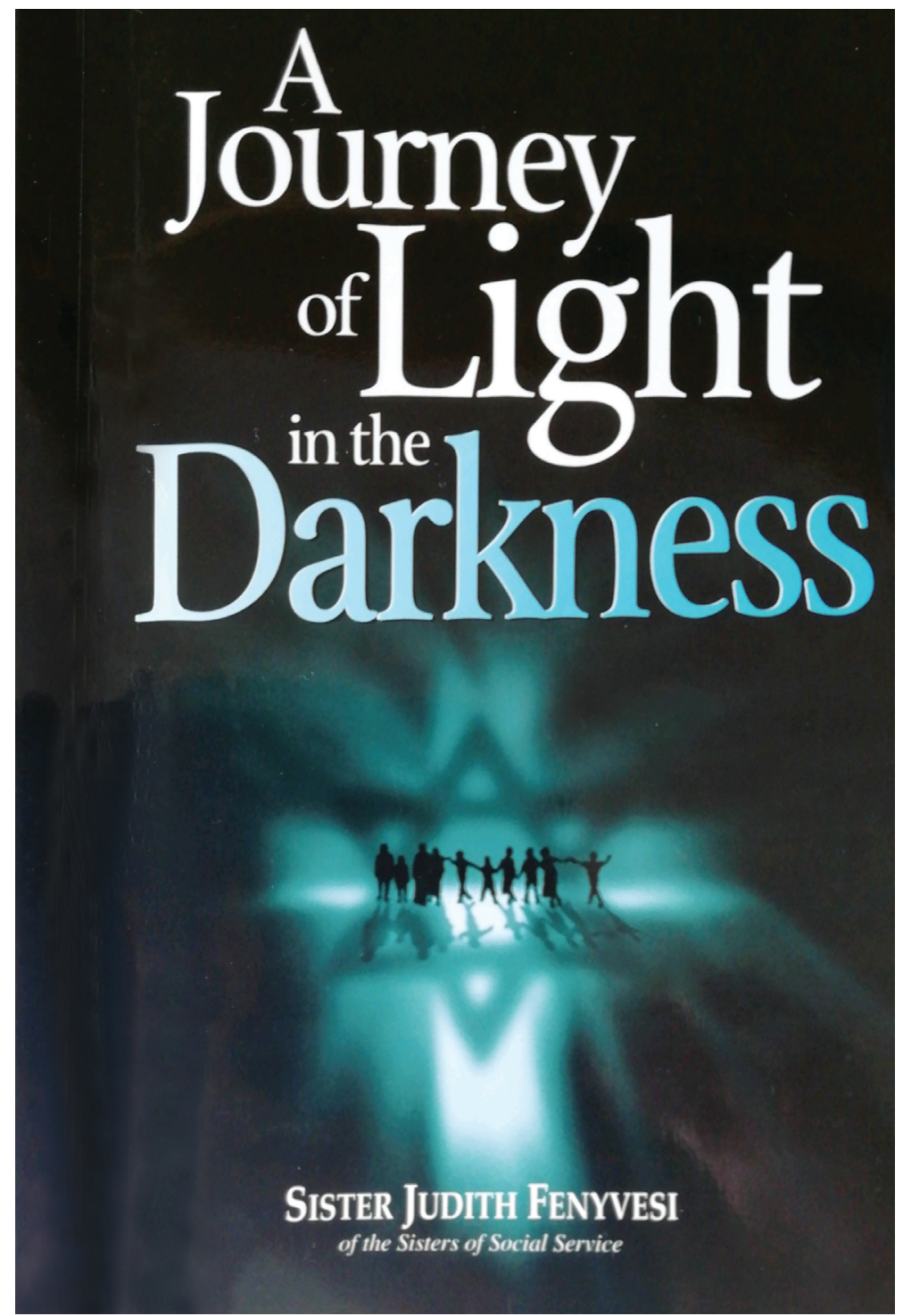

Sister Judith Fenyvesi: A Journey of Light in the Darkness cimú önéletírás boritóképe 